\title{
Effect of Different Plant Growth Regulators and Methods of Application on Seed Yield and Quality of Coriander (Coriandrum sativum L.)
}

\author{
S. P. Deokar", A. P. Wagh, P. K. Nagre, V. S. Kale and R. D. Walke \\ Department of Vegetable Science, Faculty of Horticulture, Dr. Panjabrao Deshmukh Krishi \\ Vidyapeeth, Akola, Maharashtra, India \\ *Corresponding author
}

\section{A B S T R A C T}

\begin{tabular}{|l|}
\hline K e y w o r d s \\
$\begin{array}{l}\text { Characters, } \\
\text { Coriander, Foliar } \\
\text { spray, Seed, Seed } \\
\text { soaked, 50\% } \\
\text { flowering }\end{array}$ \\
\hline Article Info \\
\hline $\begin{array}{l}\text { Accepted: } \\
\text { 22 November } 2020 \\
\text { Available Online: } \\
\text { 10 December } 2020\end{array}$ \\
\hline
\end{tabular}

A field experiment was conducted during rabi 2018-2019 @ instructional farm department of vegetable science, Dr. PDKV, Akola to study the effect of different plant growth regulators and methods of application on seed yield and quality of coriander. The experiment consists of eighteen treatment combination viz., $\mathrm{T}_{1}-\mathrm{GA}_{3}$ $50 \mathrm{ppm}$ seed soaked, $\mathrm{T}_{2}-\mathrm{GA}_{3} 75 \mathrm{ppm}$ seed soaked, $\mathrm{T}_{3}-\mathrm{GA}_{3} 100 \mathrm{ppm}$ seed soaked, $\mathrm{T}_{4}$ CCC $200 \mathrm{ppm}$ seed soaked, $\mathrm{T}_{5}$ - CCC $250 \mathrm{ppm}$ seed soaked, $\mathrm{T}_{6}-$ CCC $300 \mathrm{ppm}$ seed soaked, $\mathrm{T}_{7}-\mathrm{GA}_{3} 50 \mathrm{ppm}$ foliar spray, $\mathrm{T}_{8}-\mathrm{GA}_{3} 75 \mathrm{ppm}$ foliar spray, $\mathrm{T}_{9}-\mathrm{GA}_{3} 100 \mathrm{ppm}$ foliar spray, $\mathrm{T}_{10}$ - CCC $200 \mathrm{ppm}$ foliar spray, $\mathrm{T}_{11}$ - CCC $250 \mathrm{ppm}$ foliar spray, $\mathrm{T}_{12}$ CCC $300 \mathrm{ppm}$ foliar spray, $\mathrm{T}_{13}-\mathrm{GA}_{3} 50 \mathrm{ppm}(\mathrm{S}+\mathrm{F}), \mathrm{T}_{14}-\mathrm{GA}_{3} 75 \mathrm{ppm}(\mathrm{S}+\mathrm{F}), \mathrm{T}_{15}$ $\mathrm{GA}_{3} 100 \mathrm{ppm}(\mathrm{S}+\mathrm{F}), \mathrm{T}_{16} \mathrm{CCC} 0200 \mathrm{ppm}(\mathrm{S}+\mathrm{F}), \mathrm{T}_{17} \mathrm{CCC} 250 \mathrm{ppm}(\mathrm{S}+\mathrm{F}), \mathrm{T}_{18}$ CCC $300 \mathrm{ppm}(\mathrm{S}+\mathrm{F})$. Among different treatment combinations $\mathrm{M}_{3} \mathrm{P}_{6}$ resulted in significantly maximum result in respect to yield parameters andM ${ }_{3} \mathrm{P}_{3}$ found significantly superior results for all quality contributing characters.

\section{Introduction}

Spices are nature's gift to humankind as they add flavour to our food. In addition, they also have preservative and medicinal values (Anonymous, 2015). Spices are almost indispensable in the culinary art, which constitute an important group of horticultural commodities.

Total 109 spices are listed by ISO and 63 spices are grown in India and out of which twenty are being classified as seed spices. Among the seed spices, coriander occupies prominent place than any other seed spices viz., cumin, fenugreek, ajwain, fennel, dill, aniseed, caraway, celery and mustard etc. The seeds have the lemony flavour when crushed, which is due to terpenes, linalool and pinene. The roots have more intense flavour than leaves and are commonly used in Thai preparations.

Coriander is most widely used seed spice crop by entire mankind of the world. The botanical name of coriander is Coriandrum sativum $\mathrm{L}$. which belongs to family Umbellifereae having chromosome number $2 n=22$. Plant 
breeders and the seed traders, often refer to two main group of coriander based on fruit size: var. Vulgare (large fruits) and var. Microcarpum (small fruits). The fruits are reported to have carminative, diuretic, tonic, stomachic, antibilious, refrigerant, anticatarrhal, antispasmodic, galactagougue, emmenagogue and aphrodisiac effects.

The seeds measures about 4-6 $\mathrm{mm}$ in diameter with a central hollow cavity containing two vertical vittae containing some important essential oils, which is used as flavoring agent as an ingredient in pharmaceutical formulation and in perfumery (Singh etal., 2006).

The fruits consist of two halves, the single seeded mericarps (Pruthi, 1997). The odour and taste are due to the compound containing d- linalool or coriandrol. The seed contains $16.15 \%$ fatty oils $14.1 \%$ protein, $21.6 \%$ carbohydrates, $32.6 \%$ fibers, $11.2 \%$ moistures and $4.4 \%$ mineral matters and coriander leaves are very rich in vitamin A and vitamin $\mathrm{C}$.

India leads in production, consumption and exporter of spices in the world. Arid and semiarid parts of the India are known as "Spices Bowl" (Rajasthan and Gujarat)assist more than $80 \%$ of the total seed spices production.

Plant growth regulators (PGRs), are the magical chemicals that could increase horticultural production at an unprecedented rate and help in removing or circumventing many of the barrier imposed by genetics and environment (Nickel, 1982).

Effectiveness of plant growth regulators depends upon many factors viz. methods of application, concentration of PGRs and time of application.

\section{Materials and Methods}

The field experiment was carried out during rabi season of academic year 2018-19, at Instructional Farm, Department of Vegetable Science, Dr. Panjabrao Deshmukh Krishi Vidyapeeth, Akola (M.S.) in Factorial Randomized Block Design with three replications and eighteen treatment combinations.

The seed material used for the present investigation was variety pant haritima which was procured from the GBPUA and T, Pantanagar. There were two factors, main factor being methods of application of PGRs (three) and another sub factor was six concentrations of PGRs ( $\mathrm{GA}_{3}$ and $\left.\mathrm{CCC}\right)$.

In present investigation three concentration of $\mathrm{GA}_{3}$ and $\mathrm{CCC}$ were used at different growth stage (30 and 45 DAS). The crop was fertilized with NPK @ 60:20:30 Kg ha ${ }^{-1}$ (ICAR, Recommendation).Gap filling was performed 20 days after sowing.

Need based cultural and plant protection operations were taken up to harvest. Five plants from each treatment combination were selected at random to record data on yield attributing characters and quality aspects of coriander. The test weight was calculated by counting weight of 1000 seed. The experimental data was analysed statistically by the method of analysis of variance as out lined by Panse and Sukhatme (1995).

\section{Experimental details}

Design: Factorial Randomized Block Design

Replications: Three

Treatment combinations: 18

Total plots: 54

Plot size: 1.8 x $1.20 \mathrm{~m}$

Plant spacing: $30 \times 10 \mathrm{~cm}$ 


\section{Treatment Details}

\begin{tabular}{|c|c|c|}
\hline Treatments & $\begin{array}{c}\text { Treatment } \\
\text { combinations }\end{array}$ & Treatment Details \\
\hline $\mathbf{T}_{1}$ & $\mathrm{M}_{1} \mathrm{P}_{1}$ & $\mathrm{GA}_{3} 50 \mathrm{ppm}$ seed soaked \\
\hline $\mathbf{T}_{2}$ & $\mathrm{M}_{1} \mathrm{P}_{2}$ & $\mathrm{GA}_{3} 75 \mathrm{ppm}$ seed soaked \\
\hline $\mathbf{T}_{3}$ & $\mathrm{M}_{1} \mathrm{P}_{3}$ & $\mathrm{GA}_{3} 100 \mathrm{ppm}$ seed soaked \\
\hline $\mathbf{T}_{4}$ & $\mathrm{M}_{1} \mathrm{P}_{4}$ & CCC 200 ppm seed soaked \\
\hline $\mathbf{T}_{5}$ & $\mathrm{M}_{1} \mathrm{P}_{5}$ & CCC 250 ppm seed soaked \\
\hline $\mathbf{T}_{6}$ & $\mathrm{M}_{1} \mathrm{P}_{6}$ & CCC 300 ppm seed soaked \\
\hline $\mathbf{T}_{7}$ & $\mathrm{M}_{2} \mathrm{P}_{1}$ & $\mathrm{GA}_{3} 50 \mathrm{ppm}$ foliar spray \\
\hline $\mathbf{T}_{8}$ & $\mathrm{M}_{2} \mathrm{P}_{2}$ & $\mathrm{GA}_{3} 75 \mathrm{ppm}$ foliar spray \\
\hline $\mathbf{T}_{9}$ & $\mathrm{M}_{2} \mathrm{P}_{3}$ & $\mathrm{GA}_{3} 100 \mathrm{ppm}$ foliar spray \\
\hline $\mathbf{T}_{10}$ & $\mathrm{M}_{2} \mathrm{P}_{4}$ & CCC 200 ppm foliar spray \\
\hline $\mathbf{T}_{11}$ & $\mathrm{M}_{2} \mathrm{P}_{5}$ & CCC $250 \mathrm{ppm}$ foliar spray \\
\hline $\mathbf{T}_{12}$ & $\mathrm{M}_{2} \mathrm{P}_{6}$ & CCC 300 ppm foliar spray \\
\hline $\mathbf{T}_{13}$ & $\mathrm{M}_{3} \mathrm{P}_{1}$ & $\mathrm{GA}_{3} 50 \mathrm{ppm}$ seed soaked + foliar spray \\
\hline $\mathbf{T}_{14}$ & $\mathrm{M}_{3} \mathrm{P}_{2}$ & $\mathrm{GA}_{3} 75 \mathrm{ppm}$ seed soaked + foliar spray \\
\hline $\mathbf{T}_{15}$ & $\mathrm{M}_{3} \mathrm{P}_{3}$ & $\mathrm{GA}_{3} 100 \mathrm{ppm}$ seed soaked + foliar spray \\
\hline $\mathbf{T}_{16}$ & $\mathrm{M}_{3} \mathrm{P}_{4}$ & CCC 200 ppm seed soaked + foliar spray \\
\hline $\mathbf{T}_{17}$ & $\mathrm{M}_{3} \mathrm{P}_{5}$ & CCC $250 \mathrm{ppm}$ seed soaked + foliar spray \\
\hline $\mathbf{T}_{18}$ & $\mathrm{M}_{3} \mathrm{P}_{6}$ & CCC 300 ppm seed soaked + foliar spray \\
\hline
\end{tabular}

\section{Results and Discussion}

\section{Flowering parameters}

\section{Days required to first flowering}

The data regarding days required to first flowering as influenced by different plant growth regulators (PGRs) and methods of application was presented in Table 1 .

\section{Effect of methods of application of PGRs}

A perusal of the data indicated that significantly minimum days required to first flowering (29.66) was recorded when PGRs applied as seed soaked + foliar spray $\left(\mathrm{M}_{3}\right)$. However, it was recorded maximum (37.77) when applied as seed soaked $\left(\mathrm{M}_{1}\right)$.

\section{Effect of concentration of PGRs}

The application of PGRs with different concentrations on coriander plant influence significantly. Significantly minimum days required to first flowering (30.00) was noticed with an application of $\mathrm{GA}_{3} @ 100$ ppm $\left(\mathrm{P}_{3}\right)$ which was found at par with $\mathrm{P}_{2}$. Whereas, maximum days required to first flowering (37.90) was recorded with an application of CCC@ 200 ppm $\left(\mathrm{P}_{4}\right)$.

\section{Interaction effect}

The data presented in Table (1) revealed that the interaction effect in between the methods of application and concentration of PGRs was found statistically significant. Significantly the minimum number of days to first flowering (27.66) was recorded when the $\mathrm{GA}_{3}$ was applied as seed soaked + foliar spray treatment combination $\left(\mathrm{M}_{3} \mathrm{P}_{3}\right)$, which was found at par with treatment combinations $\mathrm{M}_{3} \mathrm{P}_{2}, \mathrm{M}_{3} \mathrm{P}_{1}, \mathrm{M}_{3} \mathrm{P}_{6}$ and $\mathrm{M}_{2} \mathrm{P}_{3}$. While, it was recorded maximum (43.66) due to an application of CCC @ 200 ppm as seed soaked treatment combination $\left(\mathrm{M}_{1} \mathrm{P}_{4}\right)$.

Application of plant growth substances has been shown to produce early flowering due to 
fact that the plant on account of their rapid and increasing vegetative growth build up suitable carbohydrate reserved. Thus accumulation of photosynthesis in the quantity more than that required for the growth causes flower production. $\mathrm{GA}_{3}$ treated plant contain more protenious material along with chlorophyll content. There by leading to early production of flower in coriander. Similar findings were also reported by Dhage et al., (2011) in okra as well as Chatterjee and Choudhuri (2012) in cowpea.

\section{Days required to $50 \%$ flowering}

The data in regard to days required to $50 \%$ flowering as influenced by different concentration of plant growth regulators (PGRs) and methods of application were presented in Table 1.

\section{Effect of methods of application of PGRs}

A perusal of the data indicated that, significantly minimum days required to $50 \%$ flowering (42.77) was recorded when PGRs applied as seed soaked + foliar spray $\left(\mathrm{M}_{3}\right)$. However, it was recorded maximum (50.38) when applied as seed soaked $\left(\mathrm{M}_{1}\right)$.

\section{Effect of concentration of PGRs}

The application of PGRs with different concentrations on coriander plant influence significantly. The minimum days required to $50 \%$ flowering (43.00) was noticed with an application of $\mathrm{GA}_{3} @ 100$ ppm $\left(\mathrm{P}_{3}\right)$ which was found at par with $\mathrm{P}_{2}$. Whereas, maximum days required to $50 \%$ flowering (50.80) was recorded with an application of CCC @ 200 $\operatorname{ppm}\left(\mathrm{P}_{4}\right)$.

\section{Interaction effect}

Significantly minimum number of days to 50 $\%$ flowering (40.66) was recorded when the
$\mathrm{GA}_{3}$ was applied as seed soaked + foliar spray treatment combination $\left(\mathrm{M}_{3} \mathrm{P}_{3}\right)$ which was found at par with treatment combinations $\mathrm{M}_{3} \mathrm{P}_{2}, \mathrm{M}_{3} \mathrm{P}_{1}$ and $\mathrm{M}_{3} \mathrm{P}_{6}$. While, it was recorded maximum (56.33) due to an application of CCC @ 200 ppm as seed soaked treatment combination $\left(\mathrm{M}_{1} \mathrm{P}_{4}\right)$.

This might be due to the fact that $\mathrm{GA}_{3}$ involvement in transition of vegetative apices to floral apices. According to Lang (1965), $\mathrm{GA}_{3}$ could substitute for the proper environmental conditions which initiates early flowering. The similar results in this regard were reported by Haokip et al., (2016), Yugandhar et al., (2017) and Kurmi et al., (2019) in coriander.

\section{Yield parameters}

\section{Number of umbels per plant}

The data regarding number of umbels per plant as influenced by different concentration of plant growth regulators (PGRs) and methods of application is presented in Table 1.

\section{Effect of methods of application of PGRs}

It is opined from the data presented in an application of PGRs with Table 1 that significantly maximum number of umbels per plant (26.95) were recorded when applied as seed soaked + foliar spray $\left(\mathrm{M}_{3}\right)$. However, it was recorded minimum (20.25) when applied as seed soaked $\left(\mathrm{M}_{1}\right)$.

\section{Effect of concentration of PGRs}

The application of PGRs with different concentration on coriander plant showed statistically significant differences. Significantly the maximum number of umbels (26.10) were recorded with an application CCC @ 300 ppm $\left(\mathrm{P}_{6}\right)$ which was found at par 
with $\mathrm{P}_{5}$. Whereas, significantly minimum number of umbels (20.25) were noticed with an application of $\mathrm{GA}_{3} @ 50 \mathrm{ppm}\left(\mathrm{P}_{1}\right)$.

\section{Interaction effect}

The data presented in Table (1) revealed that the interaction effect in between the methods of application and concentration of PGRs was found statistically significant. Significantly maximum (31.97) number of umbels per plant were recorded due to an application of CCC @ $300 \mathrm{ppm}$ as seed soaked + foliar spray treatment combination $\left(\mathrm{M}_{3} \mathrm{P}_{6}\right)$. While, it was recorded minimum (17.50) when $\mathrm{GA}_{3}$ was applied @ 50 ppm as seed soaked treatment combination $\left(\mathrm{M}_{1} \mathrm{P}_{1}\right)$. This might be due to the fact that, the increase in number of umbels per plant could be attributed due to the increase in the number of branches per plant. Similar results were reported by Yugandhar et al., (2017) and Kurmi et al., (2019) in coriander.

\section{Number of umbellets per umbel}

The data regarding number of umbellets per umbel as influenced by different concentration of plant growth regulators (PGRs) and methods of application is presented in Table 1.

\section{Effect of methods of application of PGRs}

It is opined from the data presented in an application of PGRs with Table 1 that significantly the maximum number of umbellets per umbel (6.76) were recorded when PGRs applied as seed soaked + foliar spray $\left(\mathrm{M}_{3}\right)$. However, it was recorded minimum (6.06) when applied as seed soaked $\left(\mathrm{M}_{1}\right)$.

\section{Effect of concentration of PGRs}

The application of PGRs with different concentration on coriander plant showed statistically significant differences. Significantly maximum number of umbellets per umbel (7.34) were recorded with an application of $300 \mathrm{ppm} \mathrm{CCC}\left(\mathrm{P}_{6}\right)$. Whereas, significantly minimum number of umbellets per umbel (5.26) were noticed with an application of $\mathrm{GA}_{3} @ 50 \mathrm{ppm}\left(\mathrm{P}_{1}\right)$.

\section{Interaction effect}

The data presented in Table (1) revealed that the interaction effect in between the methods of application and concentration of PGRs was found statistically significant. Significantly the maximum number of umbellets per umbel (7.86) were recorded due to an application of CCC@300 ppm as seed soaked + foliar spray treatment combination $\left(\mathrm{M}_{3} \mathrm{P}_{6}\right)$. While, it was recorded minimum (5.10) when the $\mathrm{GA}_{3}$ was applied as seed soaked treatment combination $\left(\mathrm{M}_{1} \mathrm{P}_{1}\right)$.

This might be due to the fact that, the increase in number of umbellets per umbel by CCC might be due to accumulation of metabolites stimulation get translocated towards the reproductive sinks and these in turn resulted in stimulation of umbellets. Similar results were reported by Haokip et al., (2016), Yugandhar et al., (2017)and Kurmi et al (2019) in coriander.

\section{Days required to harvesting}

The data pertaining to days required to harvesting as influenced by different concentrations of plant growth regulators (PGRs) and methods of application were recorded and presented in Table 1.

\section{Effect of methods of application of PGRs}

It is opined from the data presented in an application of PGRs with Table 1 that significantly minimum days required to harvesting (104.17) were recorded when 
PGRs applied as seed soaked + foliar spray $\left(\mathrm{M}_{3}\right)$. However, it was recorded maximum (113.11) when applied as seed soaked $\left(\mathrm{M}_{1}\right)$.

\section{Effect of concentration of PGRs}

The application of PGRs with different concentration on coriander plant showed statistically significant differences. significantly minimum number of days required to harvesting (105.00) were noticed with an application of $\mathrm{GA}_{3} @ 100$ ppm $\left(\mathrm{P}_{3}\right)$ which was found at par with $\mathrm{P}_{2}$. Whereas, significantly maximum number of days required to harvesting (113.00) were recorded with an application of $200 \mathrm{ppm} \mathrm{CCC}\left(\mathrm{P}_{4}\right)$.

\section{Interaction effect}

Significantly the minimum days required to harvesting (98.33) was recorded when the $\mathrm{GA}_{3}$ was applied @ 100 ppm as seed soaked + foliar spray treatment combination $\left(\mathrm{M}_{3} \mathrm{P}_{3}\right)$, which was found at par with treatment combination $\mathrm{M}_{3} \mathrm{P}_{2}$. While, it was recorded maximum (116.00) due to an application of CCC @ 200 ppm as seed soaked treatment combination $\left(\mathrm{M}_{1} \mathrm{P}_{4}\right)$.

Early flowering and harvesting in $\mathrm{GA}_{3}$ treatment might be due to its involvement in transition of vegetative apices to floral apices. According to Lang (1965) $\mathrm{GA}_{3}$ could substitute for the proper environmental conditions which initiate early flowering and there by harvesting. Similar findings were also reported by Panda et al., (2007) and Yugandhar et al., (2014) in coriander.

\section{Number of seeds per umbel}

The data related to number of seeds per umbel as influenced by different concentration of plant growth regulators (PGRs) and methods of application were recorded and presented in Table 1.

\section{Effect of methods of application of PGRs}

It is observed from the data presented in an application of PGRs with Table 1 that significantly the maximum number of seeds per umbel (39.01) were recorded when PGRs applied as seed soaked + foliar spray $\left(\mathrm{M}_{3}\right)$. However, it was recorded minimum (27.70) when applied as seed soaked $\left(\mathrm{M}_{1}\right)$.

\section{Effect of concentration of PGRs}

The application of PGRs with different concentration on coriander plant showed statistically significant differences. Significantly the maximum number of seeds per umbel (39.00) was recorded with an application of CCC @ $300 \mathrm{ppm} \quad\left(\mathrm{P}_{6}\right)$. Whereas, significantly the minimum number of seeds per umbel (25.65) was noticed with an application of $\mathrm{GA}_{3} @ 50 \mathrm{ppm}\left(\mathrm{P}_{1}\right)$.

\section{Interaction effect}

The interaction effect in between the methods of application and concentration of PGRs was found statistically significant (Table 1). Significantly the maximum number of seeds per umbel (46.00) was recorded due to an application of CCC @ 300 ppm as seed soaked + foliar spray treatment combination $\left(\mathrm{M}_{3} \mathrm{P}_{6}\right)$, which was found at par with treatment combination $\mathrm{M}_{3} \mathrm{P}_{5}$. While, it was recorded minimum (20.40) when the $\mathrm{GA}_{3}$ was applied @ 50 ppm as seed soaked treatment combination $\left(\mathrm{M}_{1} \mathrm{P}_{1}\right)$. There were increase in the number of seeds per umbel in coriander with increase in level of CCC viz. more number of umbellets with seed soaked + foliar spray than only single mode of application in the present investigation. This might be due to the fact that the increase in number of seeds per umbel could be attributed to the increase in the number of umbellets per umbel by CCC. Similar results were reported by Yugandhar et al., (2014), Yugandhar et al., (2017) and Kurmi et al., (2019) in coriander. 
Table.1 Effect of different plant growth regulators and methods of application on flowering and yield parameters

\begin{tabular}{|c|c|c|c|c|c|c|c|c|c|}
\hline \multirow[t]{2}{*}{ Treatments } & \multicolumn{2}{|c|}{ Flowering parameters } & \multicolumn{7}{|c|}{ Yield parameters } \\
\hline & $\begin{array}{l}\text { Days to } 1^{\mathrm{st}} \\
\text { flowering }\end{array}$ & $\begin{array}{l}\text { Days to } 50 \% \\
\text { flowering }\end{array}$ & $\begin{array}{l}\text { Number of umbels } \\
\text { per plant }\end{array}$ & $\begin{array}{l}\text { Number of umbellets } \\
\text { per umbel }\end{array}$ & Days to harvesting & $\begin{array}{r}\text { Number of } \\
\text { seeds per umbel }\end{array}$ & $\begin{array}{l}\text { Seed yield per } \\
\text { plant }(\mathrm{g})\end{array}$ & $\begin{array}{l}\text { Seed yield per } \\
\text { plot(kg) }\end{array}$ & $\begin{array}{l}\text { Seed yield per } \\
\text { hectare }(q)\end{array}$ \\
\hline \multicolumn{10}{|c|}{ Methods of Application of PGRs (M) } \\
\hline $\mathbf{M}_{1}$ ( Seed soaked) & 37.77 & 50.38 & 20.25 & 6.06 & 113.11 & 27.70 & 6.48 & 0.30 & 13.95 \\
\hline $\mathbf{M}_{2}$ (Foliar spray) & 33.55 & 46.38 & 22.37 & 6.28 & 109.22 & 31.44 & 7.30 & 0.33 & 15.37 \\
\hline$M_{3}($ Seed soaked + foliar spray) & 29.66 & 42.77 & 26.95 & 6.76 & 104.17 & 39.01 & 8.27 & 0.37 & 17.25 \\
\hline 'F' test & Sig & Sig & Sig & Sig & Sig & Sig & Sig & Sig & Sig \\
\hline $\mathrm{SE}(\mathrm{m}) \pm$ & 0.39 & 0.37 & 0.30 & 0.06 & 0.38 & 0.31 & 0.07 & 0.0032 & 0.15 \\
\hline CD at $5 \%$ & 1.13 & 1.08 & 0.87 & 0.18 & 1.11 & 0.89 & 0.20 & 0.009 & 0.43 \\
\hline \multicolumn{10}{|l|}{ Concentration of PGRs (P) } \\
\hline$P_{1}\left(G_{4}-50\right.$ ppm $)$ & 31.88 & 44.55 & 20.25 & 5.26 & 107.44 & 25.65 & 6.47 & 0.28 & 13.26 \\
\hline$P_{2}\left(G_{4}-75\right.$ ppm $)$ & 30.70 & 43.70 & 21.40 & 5.48 & 106.00 & 26.60 & 6.95 & 0.31 & 14.30 \\
\hline$P_{3}\left(G_{3}-100 \mathrm{ppm}\right)$ & 30.00 & 43.00 & 22.92 & 6.29 & 105.00 & 30.82 & 7.13 & 0.32 & 14.80 \\
\hline$P_{4}($ CCC- 200 ppm) & 37.90 & 50.80 & 23.43 & 6.89 & 113.00 & 36.90 & 7.37 & 0.35 & 16.10 \\
\hline$P_{5}($ CCC- 250 ppm $)$ & 36.40 & 49.30 & 25.00 & 6.98 & 112.00 & 37.50 & 7.83 & 0.36 & 16.60 \\
\hline$P_{6}($ CCC- 300 ppm $)$ & 35.10 & 47.80 & 26.10 & 7.34 & 111.00 & 39.00 & 8.35 & 0.39 & 18.00 \\
\hline 'F' test & Sig & Sig & Sig & Sig & Sig & Sig & Sig & Sig & Sig \\
\hline $\mathrm{SE}(\mathbf{m}) \pm$ & 0.55 & 0.53 & 0.43 & 0.09 & 0.54 & 0.43 & 0.17 & 0.0045 & 0.21 \\
\hline CD at 5\% & 1.60 & 1.53 & 1.24 & 0.26 & 1.57 & 1.26 & 0.50 & 0.013 & 0.61 \\
\hline \multicolumn{10}{|l|}{ Interaction (M X P) } \\
\hline $\mathbf{M}_{1} \mathbf{P}_{1}$ & 35.66 & 47.66 & 17.50 & 5.10 & 112.66 & 20.40 & 6.05 & 0.2629 & 12.17 \\
\hline $\mathbf{M}_{1} \mathbf{P}_{2}$ & 33.00 & 46.00 & 17.86 & 5.26 & 111.00 & 21.06 & 6.09 & 0.2843 & 13.16 \\
\hline $\mathbf{M}_{1} \mathbf{P}_{3}$ & 32.00 & 45.00 & 19.53 & 5.40 & 110.00 & 21.60 & 6.15 & 0.2883 & 13.34 \\
\hline $\mathbf{M}_{1} \mathbf{P}_{4}$ & 43.66 & 56.33 & 21.60 & 6.76 & 116.00 & 33.83 & 6.62 & 0.2994 & 13.86 \\
\hline $\mathbf{M}_{1} \mathbf{P}_{5}$ & 41.66 & 54.66 & 22.32 & 6.83 & 115.00 & 34.16 & 6.81 & 0.3166 & 14.65 \\
\hline $\mathbf{M}_{1} \mathbf{P}_{6}$ & 40.66 & 52.66 & 22.70 & 7.03 & 114.00 & 35.16 & 7.14 & 0.3562 & 16.49 \\
\hline $\mathbf{M}_{2} \mathbf{P}_{1}$ & 31.00 & 44.00 & 20.40 & 5.26 & 108.66 & 26.33 & 6.15 & 0.2933 & 13.58 \\
\hline $\mathbf{M}_{2} \mathbf{P}_{2}$ & 30.66 & 43.66 & 21.46 & 5.40 & 107.00 & 27.00 & 6.92 & 0.2965 & 13.73 \\
\hline $\mathbf{M}_{2} \mathbf{P}_{3}$ & 30.33 & 43.33 & 22.76 & 6.40 & 106.00 & 32.00 & 7.04 & 0.3027 & 14.01 \\
\hline $\mathbf{M}_{2} \mathbf{P}_{4}$ & 38.00 & 51.00 & 22.80 & 6.70 & 112.33 & 33.50 & 7.55 & 0.3601 & 16.67 \\
\hline $\mathbf{M}_{2} \mathbf{P}_{5}$ & 36.66 & 48.66 & 23.10 & 6.83 & 111.33 & 34.16 & 7.91 & 0.3628 & 16.80 \\
\hline $\mathbf{M}_{2} \mathbf{P}_{6}$ & 34.66 & 47.66 & 23.70 & 7.13 & 110.00 & 35.68 & 8.20 & 0.3792 & 17.55 \\
\hline $\mathbf{M}_{3} \mathbf{P}_{1}$ & 29.00 & 42.00 & 22.87 & 5.43 & 101.00 & 30.21 & 7.21 & 0.3035 & 14.05 \\
\hline $\mathbf{M}_{3} \mathbf{P}_{2}$ & 28.33 & 41.33 & 24.83 & 5.76 & 99.66 & 31.71 & 7.82 & 0.3512 & 16.26 \\
\hline $\mathbf{M}_{3} \mathbf{P}_{3}$ & 27.66 & 40.66 & 26.46 & 7.06 & 98.33 & 38.86 & 8.18 & 0.3708 & 17.16 \\
\hline $\mathbf{M}_{3} \mathbf{P}_{4}$ & 32.00 & 45.00 & 25.90 & 7.20 & 109.66 & 43.22 & 7.92 & 0.3861 & 17.87 \\
\hline $\mathbf{M}_{3} \mathbf{P}_{5}$ & 31.00 & 44.66 & 29.68 & 7.27 & 108.66 & 44.05 & 8.76 & 0.39 .42 & 18.25 \\
\hline $\mathbf{M}_{3} \mathbf{P}_{6}$ & 30.00 & 43.00 & 31.97 & 7.86 & 107.66 & 46.00 & 9.70 & 0.43 .05 & 19.93 \\
\hline 'F' test & Sig & Sig & Sig & Sig & Sig & Sig & Sig & Sig & Sig \\
\hline $\mathrm{SE}(\mathrm{m}) \pm$ & 0.96 & 0.92 & 0.75 & 0.15 & 0.94 & 0.76 & 0.17 & 0.0079 & 0.36 \\
\hline CD at $5 \%$ & 2.77 & 2.65 & 2.15 & 0.45 & 2.72 & 2.18 & 0.50 & 0.023 & 1.05 \\
\hline
\end{tabular}


Table.2 Effect of different plant growth regulators and methods of application on quality parameters

\begin{tabular}{|c|c|c|c|}
\hline \multirow[t]{2}{*}{ Treatments } & \multicolumn{3}{|c|}{ Quality parameters } \\
\hline & $\begin{array}{l}\text { Test weight } \\
\text { (g) }\end{array}$ & $\begin{array}{l}\text { Germination } \\
(\%)\end{array}$ & $\begin{array}{l}\text { Oleoresin content } \\
(\%)\end{array}$ \\
\hline \multicolumn{4}{|c|}{ Methods of Application of PGRs (M) } \\
\hline$M_{1}$ ( Seed soaked) & 10.71 & 83.38 & 2.77 \\
\hline $\mathbf{M}_{2}$ (Foliar spray) & 11.20 & 84.89 & 3.04 \\
\hline $\begin{array}{l}M_{3} \text { (Seed soaked + foliar } \\
\text { spray) }\end{array}$ & 11.58 & 89.27 & 3.45 \\
\hline 'F' test & Sig & Sig & Sig \\
\hline $\operatorname{SE}(\mathbf{m}) \pm$ & 0.03 & 0.59 & 0.04 \\
\hline CD at $5 \%$ & 0.13 & 2.28 & 0.18 \\
\hline \multicolumn{4}{|l|}{ Concentration of PGRs (P) } \\
\hline$P_{1}\left(G_{3}-50\right.$ ppm $)$ & 11.38 & 86.44 & 3.23 \\
\hline$P_{2}\left(G_{3}-75\right.$ ppm $)$ & 11.60 & 87.78 & 3.38 \\
\hline$P_{3}\left(G_{3}-100\right.$ ppm $)$ & 11.80 & 88.50 & 3.52 \\
\hline$P_{4}($ CCC- 200 ppm $)$ & 10.60 & 82.83 & 2.68 \\
\hline$P_{5}($ CCC- 250 ppm $)$ & 10.70 & 84.18 & 2.77 \\
\hline$P_{6}($ CCC- 300 ppm $)$ & 10.90 & 85.39 & 2.97 \\
\hline 'F' test & Sig & Sig & Sig \\
\hline $\mathrm{SE}(\mathbf{m}) \pm$ & 0.04 & 0.83 & 0.06 \\
\hline CD at $5 \%$ & 0.18 & 3.23 & 0.26 \\
\hline \multicolumn{4}{|l|}{ Interaction (M X P) } \\
\hline $\mathbf{M}_{1} \mathbf{P}_{1}$ & 10.73 & 84.66 & 2.90 \\
\hline $\mathbf{M}_{1} \mathbf{P}_{2}$ & 11.13 & 85.00 & 3.00 \\
\hline $\mathbf{M}_{1} \mathbf{P}_{3}$ & 11.26 & 85.33 & 3.16 \\
\hline $\mathbf{M}_{1} \mathbf{P}_{4}$ & 10.16 & 81.00 & 2.43 \\
\hline $\mathbf{M}_{1} \mathbf{P}_{5}$ & 10.36 & 82.00 & 2.56 \\
\hline $\mathbf{M}_{1} \mathbf{P}_{6}$ & 10.60 & 82.33 & 2.60 \\
\hline $\mathbf{M}_{2} \mathbf{P}_{1}$ & 11.50 & 85.66 & 3.23 \\
\hline $\mathbf{M}_{2} \mathbf{P}_{2}$ & 11.66 & 86.80 & 3.36 \\
\hline $\mathbf{M}_{2} \mathbf{P}_{3}$ & 11.73 & 87.66 & 3.46 \\
\hline $\mathbf{M}_{2} \mathbf{P}_{4}$ & 10.70 & 82.16 & 2.66 \\
\hline $\mathbf{M}_{2} \mathbf{P}_{5}$ & 10.73 & 82.90 & 2.73 \\
\hline $\mathbf{M}_{2} \mathbf{P}_{6}$ & 10.86 & 84.19 & 2.80 \\
\hline $\mathbf{M}_{3} \mathbf{P}_{1}$ & 11.93 & 89.00 & 3.56 \\
\hline $\mathbf{M}_{3} \mathbf{P}_{2}$ & 12.00 & 91.56 & 3.76 \\
\hline $\mathbf{M}_{3} \mathbf{P}_{3}$ & 12.43 & 92.50 & 3.93 \\
\hline $\mathbf{M}_{3} \mathbf{P}_{4}$ & 10.90 & 85.33 & 2.93 \\
\hline $\mathbf{M}_{3} \mathbf{P}_{5}$ & 11.03 & 87.63 & 3.00 \\
\hline $\mathbf{M}_{3} \mathbf{P}_{6}$ & 11.20 & 89.83 & 3.50 \\
\hline 'F' test & Sig & NS & NS \\
\hline SE(m) \pm & 0.08 & - & - \\
\hline CD at $1 \%$ & 0.32 & - & - \\
\hline
\end{tabular}


Fig.1 Interaction effect of different concentration of PGRs and methods of application on seed yield

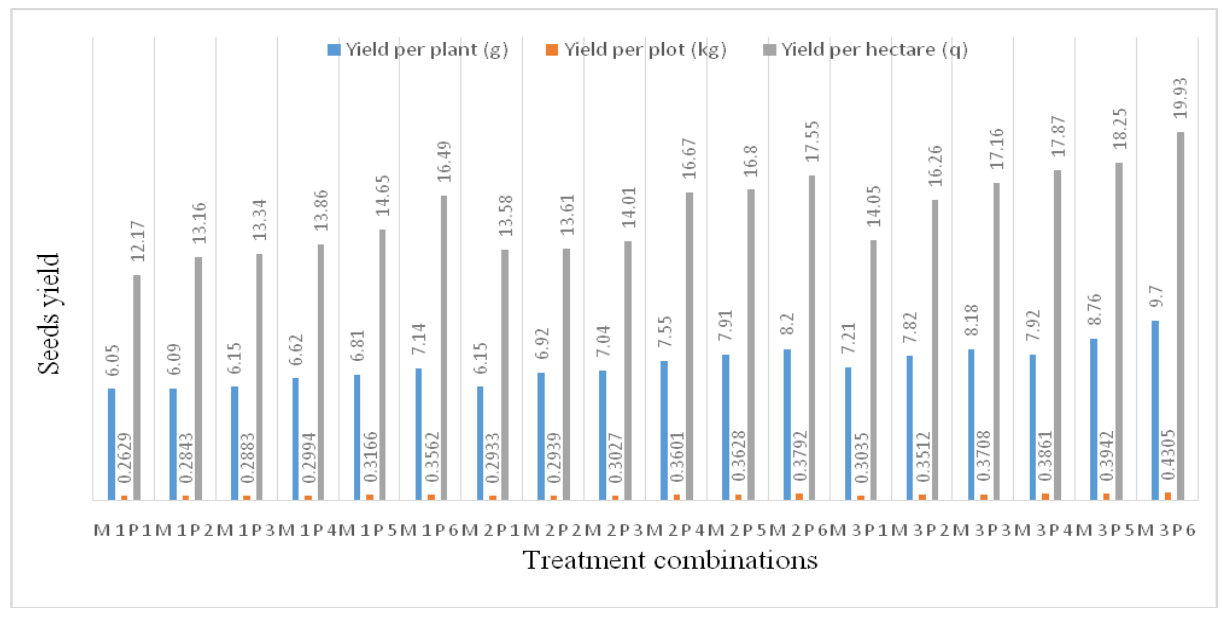

\section{Seed yield}

The data pertaining to seed yield as influenced by different concentration of plant growth regulators (PGRs) and methods of application were recorded and presented in Table 1.

\section{Effect of methods of application of PGRs}

The seed yield per plant (g), seed yield per plot $(\mathrm{kg})$ and seed yield per hectare (q) exhibited significant differences. Significantly maximum seed yield $(8.27(\mathrm{~g}), 0.37(\mathrm{~kg})$ and 17.25 (q)) was recorded when PGRs was applied as seed soaked + foliar spray $\left(\mathrm{M}_{3}\right)$. Whereas, minimum seed yield $(6.48(\mathrm{~g}), 0.30$ $(\mathrm{kg})$ and $13.95(\mathrm{q}))$ was recorded with an application of PGRs as seed soaked $\left(\mathrm{M}_{1}\right)$ respectively.

\section{Effect of concentration of PGRs}

The effect of various concentrations of PGRs on seed yield was statistically significant. For seed yield per plant $(\mathrm{g})$, seed yield per plot $(\mathrm{kg})$ and seed yield per hectare (q) significantly maximum seed yield $(8.35(\mathrm{~g})$, $0.39(\mathrm{~kg})$ and $18.00(\mathrm{q}))$ was recorded when CCC was applied @ 300 ppm $\left(\mathrm{P}_{6}\right)$. Whereas, minimum seed yield $(6.47(\mathrm{~g}), 0.28(\mathrm{~kg})$ and 13.26 (q)) was recorded when $\mathrm{GA}_{3}$ was applied @ 50 ppm $\left(\mathrm{P}_{1}\right)$.

\section{Interaction effect}

It is evident from the data presented in Table (1), seed yield per plant (g), seed yield per plot $(\mathrm{kg})$ and seed yield per hectare (q) was found maximum $(9.70(\mathrm{~g}), 0.4305(\mathrm{~kg})$ and 19.93 (q) when CCC was applied @ 300 ppm as seed soaked + foliar spray $\left(\mathrm{M}_{3} \mathrm{P}_{6}\right)$. Whereas, the minimum $(6.05(\mathrm{~g}), 0.2629(\mathrm{~kg})$ and 12.17 (q)) seed yield was noticed when $\mathrm{GA}_{3}$ was applied @ 50 ppm as seed soaked application $\left(\mathrm{M}_{1} \mathrm{P}_{1}\right)$. From the expression of result of the data presented about seed yield of coriander plant, it was observed that the seed yield was increase with the increase in the concentration of CCC. More seed yield per hectare in coriander occurs due to application of CCC @ 300 ppm as seed soaked + foliar spray treatment combination $\left(\mathrm{M}_{3} \mathrm{P}_{6}\right)$. The increase in seed yield might be due to increase in yield attributes such as number of umbels per plant, number of umbellets per umbel, number of seeds per umbel and increase in growth parameters like number of branches per plant. The above results were conformity with findings of 
Yugandhar et al., (2014) and Yugandhar et al., (2017) in coriander.

\section{Quality attributing parameters}

\section{Test weight (g)}

The data regarding test weight (g) as influenced by different concentration of plant growth regulators (PGRs) and methods of application was presented in Table 2 .

\section{Effect of methods of application of PGRs}

A perusal of the data indicated that significantly maximum test weight of seed (11.58 g) was recorded when applied as seed soaked + foliar spray $\left(\mathrm{M}_{3}\right)$. However, it was recorded minimum (10.71 $\mathrm{g}$ ), when applied as seed soaked $\left(\mathrm{M}_{1}\right)$.

\section{Effect of concentration of PGRs}

The application of PGRs with different concentration on coriander plant influence significantly. The maximum test weight of seed $(11.80 \mathrm{~g})$ was recorded with an application of $\mathrm{GA}_{3} @ 100$ ppm $\left(\mathrm{P}_{3}\right)$. Whereas, significantly minimum test weight of seed $(10.60 \mathrm{~g})$ was noticed with an application of CCC @ 200 ppm $\left(\mathrm{P}_{4}\right)$.

\section{Interaction effect}

The data presented in Table (2) revealed that the interaction effect in between the methods of application and concentration of PGRs was found statistically significant. Significantly maximum test weight of seed (12.43 g) was recorded due to an application of $100 \mathrm{ppm}$ $\mathrm{GA}_{3}$ as seed soaked + foliar spray treatment combination $\left(\mathrm{M}_{3} \mathrm{P}_{3}\right)$. While, it was recorded minimum (10.16 g) when the CCC was applied as seed soaked treatment combination $\left(\mathrm{M}_{1} \mathrm{P}_{4}\right)$.
There were increase in the test weight $(\mathrm{g})$ in coriander with different methods of application of PGRs viz. more test weight of seed with seed soaked + foliar spray $\left(\mathrm{M}_{3} \mathrm{P}_{3}\right)$ than other methods of application in the present investigation. It might be due to apportioning efficiency viz. increased allocation of photosynthesis towards the economic part and hormonal balance in the plant system. The promoting effect of $\mathrm{GA}_{3}$ on DNA, RNA and protein synthesis as well as ribose and polyribosome multiplication would contribute toward biomass production of vegetative part as well as test weight of seed. The similar results in this regard were reported by Panda et al., (2007) and Singh et al., (2012) in coriander.

\section{Germination (\%)}

The data in regard to germination (\%) as influenced by different concentration of plant growth regulators (PGRs) and methods of application was presented in Table 2 .

\section{Effect of methods of application of PGRs}

A perusal of the data indicated that, significantly maximum germination of seed (89.27\%) was recorded when applied as seed soaked + foliar spray $\left(\mathrm{M}_{3}\right)$. However, it was recorded minimum $(83.38 \%)$ when applied as seed soaked $\left(\mathrm{M}_{1}\right)$.

\section{Effect of concentration of PGRs}

The application of PGRs with different concentration on coriander plant influence significantly. The maximum germination of seed $(88.50 \%)$ was recorded with an application of $\mathrm{GA}_{3} @ 100$ ppm $\left(\mathrm{P}_{3}\right)$ which was found at par with $\mathrm{P}_{2}, \mathrm{P}_{1}$ and $\mathrm{P}_{6}$. Whereas, significantly minimum germination of seed $(82.83 \%)$ was noticed with an application of CCC @ 200 ppm $\left(\mathrm{P}_{4}\right)$. 


\section{Interaction effect}

The data presented in Table (2) depicted that the interaction effect in between the methods of application and concentration of PGRs was found statistically non-significant.It might be due to apportioning efficiency viz. increased allocation of photosynthesis towards the economic part and hormonal balance in the plant system. The promoting effect of $\mathrm{GA}_{3}$ on DNA, RNA and protein synthesis as well as ribose and polyribosome multiplication would contribute toward biomass production of vegetative part as well as test weight of seed. The similar results in this regard were reported by Panda et al., (2007) and Singh et al., (2012) in coriander.

\section{Oleoresin content (\%)}

The data regarding oleoresin content $(\%)$ as influenced by different concentration of plant growth regulators (PGRs) and methods of application was presented in Table 2 .

\section{Effect of methods of application of PGRs}

A perusal of the data indicated that, significantly maximum oleoresin content of seed $(3.45 \%)$ was recorded when applied as seed soaked + foliar spray $\left(\mathrm{M}_{3}\right)$. However, it was recorded minimum (2.77 \%) when applied as seed soaked $\left(\mathrm{M}_{1}\right)$.

\section{Effect of concentration of PGRs}

The application of PGRs with different concentration on coriander plant influence significantly. The maximum oleoresin content of seed $(3.52 \%)$ was recorded with an application of $\mathrm{GA}_{3} @ 100 \mathrm{ppm}\left(\mathrm{P}_{3}\right)$ which was found at par with $\mathrm{P}_{2}$. Whereas, significantly minimum oleoresin content of seed $(2.68 \%)$ was noticed with an application of CCC @ 200 ppm ( $\left.\mathrm{P}_{4}\right)$.

\section{Interaction effect}

The data presented in Table (2) examined that the interaction effect in between the methods of application and concentration of PGRs was found statistically non-significant. The positive effect of foliar application of growth regulators on oleoresin content might be attributed to the improved over all plant growth and metabolism. The improved oleoresin content values with plant growth regulators might be because of their role in directing the translocation of metabolites to the seed which synthesize more oil in seeds. The present results are in close accordance with the findings of Kurmi et al., (2019) in coriander.

In conclusion the methods of application of plant growth regulators (PGRs) as seed soaked + foliar spray $\left(\mathrm{M}_{3}\right)$ revealed significantly maximum results in terms of yield and quality parameters. As regards to concentration of PGRs, GA $\mathrm{A}_{3} @ 100 \mathrm{ppm}\left(\mathrm{P}_{3}\right)$ revealed significantly maximum results for quality of seed and CCC @ 300 ppm $\left(\mathrm{P}_{6}\right)$ revealed significantly maximum results for yield parameters. The treatment combination $\mathrm{M}_{3} \mathrm{P}_{3}-\mathrm{GA}_{3} @ 100 \mathrm{ppm}$ as seed soaking + foliar spray show significantly maximum results for test weight (g) except germination $(\%)$ and oleoresin content (\%), whereas significantly minimum results were noticed for days required to first flowering, days required to $50 \%$ flowering and days required to harvesting and $\mathrm{M}_{3} \mathrm{P}_{6}-\mathrm{CCC} @ 300$ ppm as seed soaking + foliar spray showed significant interaction for all yield contributing characters.

\section{References}

Anonymous, 2015. (ICAR-NRCSS). http:// nrcss.res.in.

Chatterjee, R., and P. Choudhuri, 2012. Influence of foliar application of plant 
growth promoters on growth and yield of vegetable cow pea (VignaunguiculataL.). Journal of Crop and Weed, 8(1):158-159.

Dhage, A.A., P.K. Nagre, K.K. Bhangre and Anand Kumar Pappu, 2011. Effect of plant growth regulators on growth and yield parameters of okra. The Asian Journal of Horticulture, Vol. 6 (1):170172.

Haokip, C.M,. A.B. Sharangi, K. Debbarma, A.K. Ranjita Devi and C.S. Karthik, 2016. Role of plant growth regulators on the growth and yield of coriander (Coriandrum sativumL.). Journal of Crop and Weed, 12(3):33.

Lang, A., 1965. Physiology of flower initiation. Plant physiology, 15(1):13801536.

Nickell, L.G., 1982. Plant Growth Regulators. Springer-Verlag Berlin Heidelerg, New York, pp 1-3.

Panse, V.G. and P.V. Sukhatme, 1985. Statistical Methods for Agricultural Workers. Indian Council of Agricultural Research, New Delhi. 108

Panda, M.R., R. Chatterjee, A. Pariari, P.K. Chattopadhyay, A.B. Sharangi and K. Alam, 2007. Effect of growth regulators on growth, yield and quality of coriander. Indian Journal of Horticulture, 64(3):369-371.

Pruthi, J.S., 1979. Spices and Condiments. National Book Trust India, New Dehli $\left(2^{\text {nd }} E d.\right), p p: 98-102$.

Singh, D., K. Jain, S.S. Rajput, V. Khandelwal and K.N. Shiva, 2006. Genetic variation of seed yield and its componants and their association in coriander germplasm. J. Spices Arom. Crops, 15: 25-29.

Singh, D., P.P. Singh, I.S. Naruka, S.S. Rathore and R.S. Shaktawat, 2012. Effect of plant growth regulators on growth and yield of coriander.Indian $J$. Hort., 69(1): 91-93.

Yugandhar, V., P.S.S. Reddy, G.T. Sivaram and D.S. Reddy, 2014. Effect of growth regulators on growth, seed yield and quality of coriander (Coriandrum sativumL.).Plant Archives, Vol.14(2):1083-1086.

Yugandhar, V., P.S.S. Reddy, G.T. Sivaram and E. Ramesh, 2017. Impact of presoaking and foliar application of plant growth regulators on growth and seed yield of coriander (Coriandrum sativumL.). Journal of Crop and Weed, 13(1): 100-102.

Kurmi, A.K., I.S. Naruka, S.S. Kushwah and G.S. Chouhan, 2019. Effect of PGRs on growth, yield and quality of coriander (Coriandrum sativum L.) cv NRCSSAcr-1. International Journal of Current Microbiology and Applied Sciences, ISSN: 2319-7706Volume 8 Number 05.

\section{How to cite this article:}

Deokar, S. P., A. P. Wagh, P. K. Nagre, V. S. Kale and Walke, R. D. 2020. Effect of Different Plant Growth Regulators and Methods of Application on Seed Yield and Quality of Coriander (Coriandrum sativum L.). Int.J.Curr.Microbiol.App.Sci. 9(12): 3327-3338. doi: https://doi.org/10.20546/ijcmas.2020.912.397 